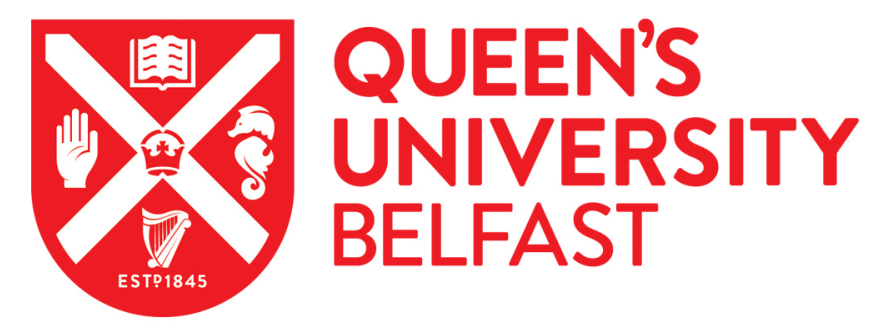

\title{
High Resolution measurement and mapping of tungstate in waters, soils and sediments using the low-disturbance DGT sampling technique.
}

Guan, D., Williams, P., Li, G., Luo, J., \& Ma, L. (2016). High Resolution measurement and mapping of tungstate in waters, soils and sediments using the low-disturbance DGT sampling technique. Journal of Hazardous Materials, 316, 69-76. https://doi.org/10.1016/j.jhazmat.2016.05.026

Published in:

Journal of Hazardous Materials

Document Version:

Peer reviewed version

Queen's University Belfast - Research Portal:

Link to publication record in Queen's University Belfast Research Portal

\author{
Publisher rights \\ (C) 2016 Elsevier. \\ This manuscript version is made available under the CC-BY-NC-ND 4.0 license (http://creativecommons.org/licenses/by-nc-nd/4.0/), which \\ permits distribution and reproduction for non-commercial purposes, provided the author and source are cited.
}

\section{General rights}

Copyright for the publications made accessible via the Queen's University Belfast Research Portal is retained by the author(s) and / or other copyright owners and it is a condition of accessing these publications that users recognise and abide by the legal requirements associated with these rights.

\section{Take down policy}

The Research Portal is Queen's institutional repository that provides access to Queen's research output. Every effort has been made to ensure that content in the Research Portal does not infringe any person's rights, or applicable UK laws. If you discover content in the Research Portal that you believe breaches copyright or violates any law, please contact openaccess@qub.ac.uk. 


\section{High-resolution measurement and mapping of tungstate in waters, soils}

and sediments using the low-disturbance DGT sampling technique

Dong-Xing Guan ${ }^{1}$, Paul N. Williams ${ }^{2}$, Hua-Cheng $\mathrm{Xu}^{3}$, Gang Li ${ }^{4}$, Jun Luo ${ }^{1, *}$, and Lena Q. $\mathrm{Ma}^{1,5}$

${ }^{1}$ State Key Laboratory of Pollution Control and Resource Reuse, School of the Environment, Nanjing University, Nanjing 210023, China

${ }^{2}$ Institute for Global Food Security, School of Biological Sciences, Queen's University Belfast, Belfast BT9 7BL, United Kingdom

${ }^{3}$ State Key Laboratory of Lake Science and Environment, Nanjing Institute of Geography and Limnology, Chinese Academy of Sciences, Nanjing 210008, China

${ }^{4}$ Institute of Urban Environment, Chinese Academy of Sciences, Xiamen 361021, China

${ }^{5}$ Soil and Water Science Department, University of Florida, Gainesville, FL 32611, USA

* Corresponding authors; 0086-25-89680632, email: esluojun@nju.edu.cn 


\begin{abstract}
Increasing tungsten (W) use for industrial and military applications has resulted in greater W discharge into natural waters, soils and sediments. Risk modeling of $\mathrm{W}$ transport and fate in the environment relies on measurement of the release/mobilization flux of $\mathrm{W}$ in the bulk media and the interfaces between matrix compartments. Diffusive gradients in thin-films (DGT) is a promising passive sampling technique to acquire such information. DGT devices equipped with the newly developed high-resolution binding gels (precipitated zirconia, PZ, or ferrihydrite, PF, gels) or classic/conventional ferrihydrite slurry gel were comprehensively assessed for measuring $\mathrm{W}$ in waters. Ferrihydrite DGT can measure $\mathrm{W}$ at various ionic strengths (0.001-0.5 mol L-1 $\mathrm{NaNO}_{3}$ ) and $\mathrm{pH}$ (4-8), while ${ }^{\mathrm{PZ}} \mathrm{DGT}$ can operate across slightly wider environmental conditions. The three DGT configurations gave comparable results for soil W measurement, showing that typically $\mathrm{W}$ resupply is relatively poorly sustained. $1 \mathrm{D}$ and $2 \mathrm{D}$ high-resolution $\mathrm{W}$ profiling across sediment-water and hotspot-bulk media interfaces from

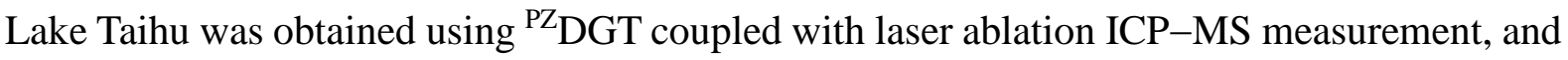
the apparent diffusion fluxes across the interfaces were calculated using a numerical model.
\end{abstract} KEY WORDS: diffusive gradients in thin-films (DGT); tungsten; precipitated zirconia (PZ) gel; sub-mm high resolution; hotspot-bulk media interface. 


\section{Introduction}

Tungsten (W) is a metal toxin with suspected carcinogenic properties [1-4]. As a dense lithophilic element noted for its hardness, superior electrical conductivity, high melting point and corrosion-resistance, $\mathrm{W}$ has a wide range of uses in daily household items (such as lamp filaments), building and construction tools (i.e. saw-blades and drill bits), specialized scientific/technological components (i.e. X-ray tubes) [5-7], industrial catalysts [8] and ammunition [9]. The country with the most acute W pollution problems is China[10]. In 2010, $85 \%$ of the $61,000 \mathrm{t}$ of $\mathrm{W}$ that were produced worldwide that year came from within Chinese borders [10], with the mineral extraction activities concentrated in the south-eastern provinces of Jiangxi and Guangdong. The pollution legacy caused by W enrichment in some of these mining districts is severe $[10,11]$. However, it's not just the manufacturing processes that are a cause of concern, leachates from E-waste repositories and recycling sites can also contain considerable amounts of $\mathrm{W}$ [12]. Measures to phase out lead in ammunition, has seen $\mathrm{W}$ being used as its replacement [13], resulting in a relatively new and poorly characterized exposure source/pathway $[1,4,9]$.

Wolframite $\left((\mathrm{Fe}, \mathrm{Mn}) \mathrm{WO}_{4}\right)$ and Scheelite $\left(\mathrm{CaWO}_{4}\right)$ are the major $\mathrm{W}$ minerals [14], and can be found within granitic intrusions and other hard rock deposits. The oxyanion $\mathrm{WO}_{4}{ }^{2-}$ is the principle soluble species $[5,15]$. The assumption that $\mathrm{W}$ is inert in soil/sediment and does not dissolve readily in water, perhaps accounts for why its biogeochemistry has not been so extensively studied compared to other toxic trace elements. However, recent research linking W to the development of a cluster of childhood leukemia cases in Neveda (USA) [13] coupled with a greater appreciation of the mobility of the element in soils/sediments and its uptake by biota, especially at pH's above $6.5[5,10,16,17]$, have led the U.S. EPA to re-classify W as an "emerging contaminant" [18]. The distribution and fate of W in the soils/water is controlled by numerous factors including: $\mathrm{pH}$, redox potential, existing chelating and precipitating agents, and $\mathrm{Fe} / \mathrm{Mn}$ concentrations [19-21]. These on-site environmental conditions can be altered during sample collection, transport and pretreatment, i.e. ex situ measurement, which can change the partitioning/bioavailability of W. For this reason, low disturbance in situ analysis techniques provide a more accurate reflection of the true solute chemistries of trace element 
biogeochemical cycles [22].

As an in situ and passive sampling technique, diffusive gradients in thin-films (DGT) has been developed to measure oxyanions, such as $\mathrm{P}$ and As, in waters and sediments [23-26]. A DGT device contains an analyte binding layer, an overlying ion-permeable diffusive layer and a protective filter $(0.45 \mu \mathrm{m})$ membrane [27]. Analytes diffuse through the filter membrane and diffusive layer from water or porewater and are immobilized onto the binding layer. DGT containing Metsorb (titanium dioxide) or mixed Chelex-Metsorb binding layers (slurry gels) have been used to measure various dissolved oxyanions including W [24, 28]. DGT loaded with a slurry ferrihydrite (SF, iron oxide) binding layer has also been reported to be able to measure $\mathrm{W}$ [29], but the sampler's performance responses to changing ionic strength, $\mathrm{pH}$ and solution W concentrations are still not known. However, all these DGT's are not suitable for high-resolution (sub-mm) spatial analysis [30], and, therefore, cannot capture the fine scale chemical processes at the interface that determine the sediment as a source or sink for W.

Tungsten has a very heterogeneous distribution in environments, such as sediments, creating dispersed but highly concentrated groupings of W hotspots [15]. These zones of intense chemical activity and localized features within them that provide mechanistic information about the uneven distribution phenomena, typically cannot be distinguished if lateral and horizontal measurements scales exceed 1-mm [31, 32]. The DGT technique provides the opportunity to quantify $\mathrm{W}$ transfer between matrixes and localized events of unusual $\mathrm{W}$ release or hotspots across sub-mm gradients if the functionalized particles that bind with the target analyte are small $(\leq 10 \mu \mathrm{m})$ and homogeneously distributed throughout the surface of the binding gel [25]. In situ precipitation of ferrihydrite and zirconia within a precast hydrogel (precipitated/high-resolution gels) has been validated as a reliable technique to meet these requirements [25, 33]. Laser-ablation (LA)-ICP-MS remains one of only a few techniques with sufficiently high sensitivities to image the multi-elements distribution patterns captured by DGT $[34,35]$. The precipitated ferrihydrite (PF) gel based DGT analyzed by LA-ICP-MS has been validated for the measurement of oxyanion transfer across sediment-water interfaces (SWI) at sub-mm scales [23]. However, one drawback of the PF gel is its limited storage time $(<40 \mathrm{~d})[33,36]$, caused by the mineral transformation of ferrihydrite to goethite and/or hematite [33]. PZ gels show little deterioration even after $>1$ year of storage and overcomes 
the above-mentioned drawback of PF gels. To date, although the PZ gel has been evaluated for six oxyanions (P, V, As, Se, Mo and Sb), the method has not yet been assessed for W.

In this study, we employed DGT containing the newly developed high-resolution PZ or PF gel, and compare the measurements to the classic/conventional SF gel to validate their performance for measuring W. Diffusion coefficients for W in the polyacrylamide diffusive gel in both synthetic and natural waters were determined. The elution efficiencies from the binding layers, the capacities and effects of $\mathrm{pH}$ and ionic strengths on $\mathrm{W}$ measurement by ${ }^{\mathrm{PZ}, \mathrm{PF} \text { and }}$

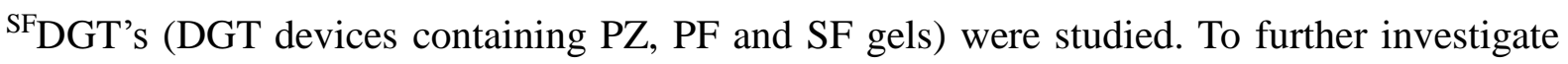

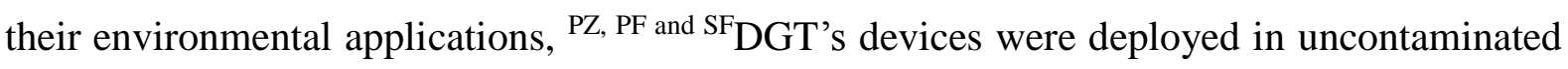
and $\mathrm{W}$ enriched soils. Finally, the high-resolution profiling of both $\mathrm{W}$ availability and matrix interface diffusion fluxes, across microniche hotspots and between sediment and overlying water were characterized using ${ }^{\text {PZDGT. }}$

\section{Materials and methods}

\subsection{Reagents, Materials, and Solutions}

MQ (18.2 $\Omega \mathrm{cm}$, Milli-Q, Millipore, USA) water was used to prepare all solutions. All chemicals were of analytical grade or better. A $1000 \mathrm{mg} \mathrm{L}^{-1} \mathrm{~W}$ stock solution $(\mathrm{pH}>6)$ was prepared freshly using $\mathrm{Na}_{2} \mathrm{WO}_{4} \cdot 2 \mathrm{H}_{2} \mathrm{O}$. A $1000 \mathrm{mg} \mathrm{L}^{-1} \mathrm{~W}$ standard solution in $0.1 \mathrm{~mol} \mathrm{~L}^{-1}$ $\mathrm{NaOH}$ matrix was obtained from China Standards Company. All plastic containers, tweezers and DGT mouldings were soaked in 1\% (v/v) alkaline (Decon 90, Decon Laboratories Ltd.) solution for $1 \mathrm{~d}$, and $10 \%$ (v/v) $\mathrm{HNO}_{3}$ (AR grade, Sinopharm Chemical Reagent Co., Ltd.) for another day, followed by thorough rinsing with MQ water prior to use.

\subsection{Laboratory evaluation of DGT performance}

\subsubsection{Gel preparation}

Diffusive gel strips $(0.8 \mathrm{~mm}$ thickness, $\sim 13 \mathrm{~cm} \times 13 \mathrm{~cm})$ were prepared following a published procedure [27]. PZ, PF and SF gel strips (0.4 mm thickness, $\sim 7 \mathrm{~cm} \times 22 \mathrm{~cm}$ ) were made according to Guan et al. [25], Luo et al. [33] and Zhang et al. [37], respectively. AgI gel strips ( $0.75 \mathrm{~mm}$ thickness) was also prepared to measure sulfide and locate the hotspots visually according to Guan et al. [25]. For laboratorial DGT characterization experiments, the gel strips were cut into circular discs $\left(2.5 \mathrm{~cm}\right.$ diameter) and stored in $0.01 \mathrm{~mol} \mathrm{~L}^{-1} \mathrm{NaNO}_{3}$ solution prior 
to use. For DGT deployment in sediment, the pre-cast PZ and AgI gel strips were cut into 1.8 $\mathrm{cm} \times 15 \mathrm{~cm}$ sediment stripes for DGT probe assembly [38], and soaked in $0.01 \mathrm{~mol} \mathrm{~L}^{-1} \mathrm{NaCl}$ solution before use. $\mathrm{NaCl}$ instead of $\mathrm{NaNO}_{3}$ was used as the matrix hereafter to avoid the sediment redox change induced by $\mathrm{NO}_{3}{ }^{-}[25]$.

\subsubsection{Elution efficiency}

To obtain the elution efficiency, PZ, PF and SF gel discs were pre-loaded with W by being immersed in 50 and $200 \mu \mathrm{g} \mathrm{L}-1 \mathrm{~W}$ solutions for $24 \mathrm{~h}$, and then eluted in $10 \mathrm{~mL}$ of $0.5 \mathrm{~mol} \mathrm{~L}^{-1}$ $\mathrm{NaOH}(\mathrm{PZ})$ or a mixed eluent of $1.4 \mathrm{~mol} \mathrm{~L}^{-1} \mathrm{HNO}_{3}$ and $0.1 \mathrm{~mol} \mathrm{~L}^{-1} \mathrm{HF}$ (PF and SF) [29] for another $24 \mathrm{~h}$. The ${ }^{184} \mathrm{~W}$ concentrations in the solutions before and after gel immersion and elution were measured by ICP-MS (PerkinElmer NexION 300X, USA) after a 5-fold dilution.

\subsubsection{Diffusion coefficients}

A previously described diaphragm diffusion cell made from Perspex [37] was used to measure the diffusion coefficient $\left(D_{\text {cell }}\right)$ of W. A 0.075 -cm-thick diffusive gel disc was placed between the two compartments connected by a $1.5 \mathrm{~cm}$ diameter circular window. Both compartments were filled with $50 \mathrm{~mL}$ solution with the same $\mathrm{pH}$ and ionic strength (IS), which was well stirred during the experiment. To test the possible effect of IS on the $D_{\text {cell }}$ values [39, 40], both synthetic solutions made with increasing concentrations of $\mathrm{NaNO}_{3}$ and natural water were adopted. The concentration of the $\mathrm{NaNO}_{3}$ in the synthetic solutions was adjusted to $0.0001,0.001,0.01$ or $0.5 \mathrm{~mol} \mathrm{~L}^{-1}(\mathrm{pH} 6.8)$. For the latter, a $0.45-\mu \mathrm{m}$ filtered river water with $\mathrm{pH} 7.5$ was used. The physicochemical properties of the river water sample are listed in Table $\mathrm{S} 1$ in the Supplementary material. In contrast to the receptor compartment, the solution in the source compartment contained $1 \mathrm{mg} \mathrm{L}^{-1} \mathrm{~W}$. Subsamples $(0.2 \mathrm{~mL})$ were taken from both sides every 15 min during a $2.5 \mathrm{~h}$ experiment. To test if the matrix $\left(\mathrm{NaNO}_{3}\right)$ had any adverse effects on analyte adsorption [29], the effective diffusion coefficients, $D_{\text {DGT }}$, were also measured by immersing DGT devices equipped with a PZ gel, a diffusive gel, and a $0.14 \mathrm{~mm}$ thick, $0.45 \mu \mathrm{m}$

poly(ether sulfone) filter membrane in $6 \mathrm{~L}$ of $50 \mu \mathrm{g} \mathrm{L}^{-1} \mathrm{~W}$ and $0.01 \mathrm{~mol} \mathrm{~L}^{-1} \mathrm{NaNO}_{3}$ for $80 \mathrm{~h}$. $D_{\text {cell }}$ and $D_{\text {DGT }}$ values were calculated as described previously [33, 39].

\subsubsection{Effects of ionic strength and $\mathrm{pH}$}

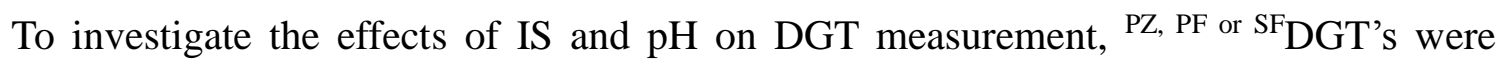
deployed in $2 \mathrm{~L}$ well-stirred solutions containing $100 \mu \mathrm{g} \mathrm{L}^{-1} \mathrm{~W}$ with $\mathrm{NaNO}_{3}$ concentrations 
from $0.1 \mathrm{mmol} \mathrm{L}^{-1}$ to $0.5 \mathrm{~mol} \mathrm{~L}^{-1}(\mathrm{pH}=6.25 \pm 0.07)$ or $\mathrm{pH}$ from 4 to 10 (IS $=0.01 \mathrm{~mol} \mathrm{~L}^{-1}$ $\mathrm{NaNO}_{3}$ ). The $\mathrm{pH}$ values were pre-adjusted with $1 \mathrm{~mol} \mathrm{~L}^{-1} \mathrm{HNO}_{3}$ or $1 \mathrm{~mol} \mathrm{~L}{ }^{-1} \mathrm{NaOH}$.

\subsubsection{Capacity}

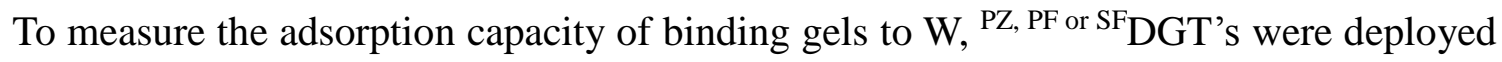
for $4 \mathrm{~h}$ in $2 \mathrm{~L}$ of well-stirred solutions containing $\mathrm{W}$ at various concentrations from 1.1 to 73.5 $\mathrm{mg} \mathrm{L}^{-1}$ and $0.01 \mathrm{~mol} \mathrm{~L}^{-1} \mathrm{NaNO}_{3}(\mathrm{pH}=6.44 \pm 0.11)$.

\subsection{Tungsten measurement in soils using ${ }^{P Z, P F}$, and ${ }^{S F} D G T$ 's}

Topsoils $(0-20 \mathrm{~cm})$ were collected from three sites in China. The first was an agricultural luvisol from Shenyang district (SY) in northeast China selected to represent baseline W concentration $\left[\mathrm{W}^{-}\right]$. The other two sites were ferralisols from mine impacted areas in southeast China, with different levels of $\mathrm{W}$ contamination. Chenzhou (CZ) from Hunan province is located in the heartland of one China's most prolific mining and base-metal smelting regions; $\mathrm{W}$ enrichment here typifies that of common mining activity within south China $\left[\mathrm{W}^{+}\right]$. Finally, severely polluted soil $\left[\mathrm{W}^{++}\right]$from Ganzhou (GZ), known as the "global capital" of W mining was sourced to provide an extreme scenario in which to challenge the DGT measurements.

After sampling, all soils were air-dried and passed through a 2-mm sieve to remove stones and plant roots. Sample $\mathrm{pH}$ was measured at a 5:1 water-to-solid ratio in $0.01 \mathrm{~mol} \mathrm{~L}^{-1} \mathrm{CaCl}_{2}$ after shaking for $1 \mathrm{~h}$ [41]. Water holding capacity (WHC) was measured by soaking the soil samples in water for $2 \mathrm{~h}$ and then draining for $2 \mathrm{~h}$ [42]. Fe, Mn and $\mathrm{Ca}$ as the primary mineral binding sites for $\mathrm{W}$ were quantified, after soil digestion (USEPA method 3050B) and detection by flame atomic absorption spectrometry (PinAAcle 900T, PerkinElmer, USA). Other soil trace elements ( $\mathrm{Pb}, \mathrm{As}, \mathrm{Cd}, \mathrm{Cr}, \mathrm{Cu}, \mathrm{Zn}, \mathrm{Ni})$ for purposes of characterization of the soil were measured by ICP-MS (see Table S2). Due to the formation of tungstate precipitate during soil acid digestion, $\mathrm{W}$ in the soils was quantified directly by portable X-ray fluorescence (Niton XL3t 980, Thermo Scientific, USA). Air-dried soil samples ( 200 g) were wetted to 50\% WHC and incubated for two days and then raised to $90 \%$ for additional $24 \mathrm{~h}$ incubation. Triplicate ${ }^{\mathrm{PZ}, \mathrm{PF}}$ and SFDGT's were gently pressed into the soil paste to keep complete contact between the soil and the filter membrane of the device [43]. They were deployed at $26 \pm 1^{\circ} \mathrm{C}$ for $24 \mathrm{~h}$ and retrieved from soils followed by rinsing with MQ water to wash off soil particles. The binding layers were removed from the devices and eluted using $10 \mathrm{~mL}$ of $0.5 \mathrm{~mol} \mathrm{~L}^{-1} \mathrm{NaOH}$ (PZ gels) 
or a mixed eluent of $1.4 \mathrm{~mol} \mathrm{~L}^{-1} \mathrm{HNO}_{3}$ and $0.1 \mathrm{~mol} \mathrm{~L}^{-1} \mathrm{HF}$ (PF and SF gels). After DGT retrieval, soil solution was collected by centrifuging at $3577 \mathrm{~g}$ for $10 \mathrm{~min}$. The soil solutions were then filtered through $0.45 \mu \mathrm{m}$ filters for analysis by ICP-MS.

\section{$2.4{ }^{P Z}$ DGT measurement in sediment}

One advantage of precipitated (PF and PZ) compared to slurry gels (SF) is their suitability for high-resolution solute profiling. Since such characteristics of PF gels have already been demonstrated [23], here only PZ gel was studied. As W contaminated sediment/soil are commonly also enriched in other trace elements (see Table S2; [11]), the improved capacity of the PZ gel over that of the PF confers some practical advantages for the measurements. Two deoxygenated ${ }^{\mathrm{PZ}} \mathrm{DGT}$ probes, one without diffusive gel and the other with AgI as the diffusive gel (both containing filter membranes) were inserted across the sediment-water interface (SWI) of two sediment cores (A and B) collected from Meiliang Bay, Lake Taihu, China. The main purpose of the AgI gel was to locate the SWI and redox microniches in the gel sampler [25, 44]. After $24 \mathrm{~h}$ deployment, the probes were retrieved followed by MQ water washing to remove sediment particles. The retrieved PZ gel from the probe with the diffusive gel were placed on polyethersulfone membranes and dried using a gel drier (Model 583, Bio-rad, USA) following an established procedure [25, 44]. Afterwards, a section $(\sim 4.5 \mathrm{~mm} \times 19.5 \mathrm{~mm})$ of the binding stripe, with the overlying AgI gel turning dark, across the SWI was cut together with the backing membrane, and mounted onto glass microscope slides with double coated carbon conductive tape (Prod No. 16073, Ted Pella, Inc., USA). The other PZ gel was sliced into two vertical columns, each of which was then cut with an interval of $0.5 \mathrm{~cm}$. The resulting rectangles were eluted in $1 \mathrm{~mL}$ of $0.5 \mathrm{~mol} \mathrm{~L}^{-1} \mathrm{NaOH}$.

High-resolution ion mapping was carried out using a LA system (UP-213, New Wave Research, USA) coupled to ICP-MS (7500 Series, Agilent Technologies, USA) to record ${ }^{13} \mathrm{C}$, and ${ }^{184} \mathrm{~W}$ signals. ${ }^{13} \mathrm{C}$ was used as an internal standard $[23,25]$. Line scans of the gels were performed at a scanning speed of $100 \mu \mathrm{m} \mathrm{s}^{-1}$, a beam diameter of $100 \mu \mathrm{m}$, a scan line interval of $150 \mu \mathrm{m}$, and a repetition rate of $5 \mathrm{~Hz}$. The laser energy level was set at $1.08 \mathrm{~J} \mathrm{~cm}^{-2}$. Warm up time and inter-line washout delay time were set at $10 \mathrm{~s}$ and $40 \mathrm{~s}$, respectively. Data processing was performed in Microsoft Excel 2013, and 1D profiles and 3D plotting of W fluxes were visualized using softwares SigmaPlot version 12.4 and ImageJ version 1.48, 
respectively.

To evaluate the transfer of $\mathrm{W}$ across geochemical interfaces, the apparent fluxes of $\mathrm{W}$ across the SWI and hotspot-bulk media interface (HS-B-I), were calculated using a numerical model [45] based on sediment properties following Eq. 1.

$$
F_{\text {total }}=F_{1}+F_{2}=D_{1} \times\left(\delta C_{\mathrm{DGT}} / \delta X_{1}\right)_{(X=0)}+D_{2} \times\left(\delta C_{\mathrm{DGT}} / \delta X_{2}\right)_{(X=0)}
$$

Here, $F_{\text {total }}$ refers to the total flux of $\mathrm{W}$ across the interface, while $F_{1}$ and $F_{2}$ represent the fluxes of W across the SWI or HS-B-I from the overlying water or bulk sediment, and from the sediment or its hotspot, respectively. DGT measured concentration gradients in the overlying water/bulk media $\left(\left(\delta C_{\mathrm{DGT}} / \delta X_{1}\right)_{(X=0)}\right)$ and sediment/hotspot $\left(\left(\delta C_{\mathrm{DGT}} / \delta X_{2}\right)_{(X=0)}\right)$ are the slopes of DGT concentration change ( $\left.\delta C_{\mathrm{DGT}}\right)$ at a given distance $\left(\delta X_{1}\right.$ or $\left.\delta X_{2}\right)$ from the interface (SWI or HS-B-I, $X=0$ ). To estimate the flux accurately and consider the size of the hotspots, the distances of $5 \mathrm{~mm}$ and $2 \mathrm{~mm}$ from the interfaces SWI and HS-B-I, respectively, were used for calculation. The diffusion coefficients $(D)$ of $\mathrm{W}$ in the overlying water/bulk media $\left(D_{1}\right)$ and sediment/hotspot $\left(D_{2}\right)$ are known based on the media, if the media is water, $D=D_{\mathrm{w}}\left(7.67 \times 10^{-6}\right.$ $\mathrm{cm}^{2} \mathrm{~s}^{-1}$ at $\left.18^{\circ} \mathrm{C}[46]\right)$, or sediment $D=D_{\mathrm{s}}=\varphi \times D_{\mathrm{w}} /\left[1-\ln \left(\varphi^{2}\right)\right]$. The porosity $(\varphi)$ of sediment was estimated at 0.9 in the top $20 \mathrm{~mm}$ layer [47].

\section{Results and discussion}

\subsection{Elution efficiency of $W$ from binding gels}

DGT-measurements require reproducible and high recoveries of $\mathrm{W}$ from the binding gels. Previous studies showed that $\mathrm{NaOH}$ and $\mathrm{HNO}_{3} / \mathrm{HF}$ were effective in eluting oxyanions such as P and As from PZ gels [25] and W from ferrihydrite gels [29]. In this study, PZ gels were eluted using $10 \mathrm{~mL}$ of $0.5 \mathrm{~mol} \mathrm{~L}^{-1} \mathrm{NaOH}$ [25], whereas PF and SF gels were eluted using $10 \mathrm{~mL}$ of $1.4 \mathrm{~mol} \mathrm{~L}^{-1} \mathrm{HNO}_{3}$ and $0.1 \mathrm{~mol} \mathrm{~L}^{-1} \mathrm{HF}$. The obtained elution efficiencies $\left(\mathrm{f}_{\mathrm{e}}\right)$ for $\mathrm{W}$ bound onto $\mathrm{PZ}, \mathrm{PF}$ and SF gels were $99.5 \pm 2.50 \%, 90.5 \pm 1.52 \%$ and $89.7 \pm 1.91 \%$, respectively. The $f_{\mathrm{e}}$ of PZ gel is comparable to the values (95.2\%-98.9\%) for oxyanions P, V, As, Se and Mo bound onto PZ gels [25]. Therefore, elution factors of 1.0 and 0.9 were adopted for the calculation of 


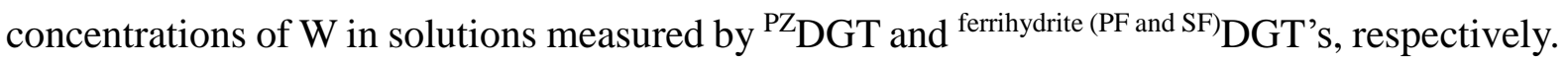
3.2 Diffusion coefficients for $W$ in the diffusive gel

The $D$ values of $\mathrm{W}$ at $25^{\circ} \mathrm{C}$ are listed in Table 1 and compared with previously published values. The $D_{\text {cell }}$ values of W at IS from $0.001 \mathrm{~mol} \mathrm{~L}^{-1}$ to $0.5 \mathrm{~mol} \mathrm{~L}^{-1}$ in this study were $6.63 \pm 0.13 \times 10^{-6} \mathrm{~cm}^{2} \mathrm{~s}^{-1}$, which was close to the values $\left(6.89 / 6.22 \times 10^{-6} \mathrm{~cm}^{2} \mathrm{~s}^{-1}\right)$ reported by Panther et al. [24, 28], but higher than the value $\left(5.45 \times 10^{-6} \mathrm{~cm}^{2} \mathrm{~s}^{-1}\right)$ proposed by Österlund et al., [29].. However, when the IS was changed to a very low level of IS at $0.1 \mathrm{mmol} \mathrm{L}^{-1}$, which is rare, the measured $D_{\text {cell }}$ value increased by $40 \%$ to $9.26 \times 10^{-6} \mathrm{~cm}^{2} \mathrm{~s}^{-1}$. Well-washed diffusive gels have a very small positive charge, so that in waters with such low IS $\left(0.1 \mathrm{mmol} \mathrm{L}^{-1}\right)$, Donnan partitioning at the gel-solution interface could occur [48], causing the effective D values of the anionic species to be elevated [33]. But such effect is negligible when IS at 0.001$0.5 \mathrm{~mol} \mathrm{~L} \mathrm{~L}^{-1}$, considering that the rather small error $(2 \%)$ is comparable to those $(1 \%-5 \%)$ measured at the same condition (IS $=0.01 \mathrm{~mol} \mathrm{~L}^{-1}$ ) $[24,28,29,49]$. This is further supported by the $D_{\text {cell }}$ value $\left(6.60 \times 10^{-6} \mathrm{~cm}^{2} \mathrm{~s}^{-1}\right)$ with the matrix being changed to authentic freshwater, which agreed quite well with the synthetic $\mathrm{NaNO}_{3}$ solutions, demonstrating the good applicability of laboratory-measured $D_{\text {cell }}$ value in field waters. The $D_{\text {DGT }}$ value $\left(6.31 \times 10^{-6} \mathrm{~cm}^{2} \mathrm{~s}^{-1}\right)$ of W in this study was close to those published by Panther et al. [24, 28] and Shiva et al. [49] $\left(6.26 / 6.88 / 6.05 / 6.50 \times 10^{-6} \mathrm{~cm}^{2} \mathrm{~s}^{-1}\right)$ but $12 \%$ higher than the value $\left(5.56 \times 10^{-6} \mathrm{~cm}^{2} \mathrm{~s}^{-1}\right)$ reported by Österlund et al. [29]. In this study, an average $D_{\text {cell }}$ value of $6.63 \times 10^{-6} \mathrm{~cm}^{2} \mathrm{~s}^{-1}$ with IS varied from 0.001 to $0.5 \mathrm{~mol} \mathrm{~L}^{-1}$ was used for the calculation of DGT-measured concentrations.

\subsection{Effects of pH and ionic strength on DGT measurement}

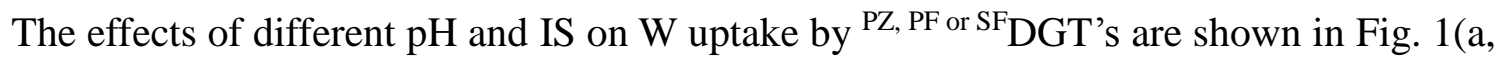
b). The overall performance of devices with the three different binding gels was similar. For $\mathrm{pH}$ in the range of 4.02-7.83, the ratio of DGT-measured concentration to solution concentration of $\mathrm{W}$ was within the acceptable limits $(1.0 \pm 0.1)$ (Fig. 1a). When $\mathrm{pH}$ reached

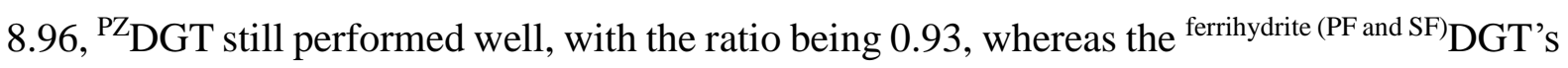
underestimated the solution concentrations, as evidenced by a low ratio value of $\sim 0.8$. However, when $\mathrm{pH}$ increased to about 10, DGT measurement significantly underestimated the solution concentration, with the ratios being 0.66 (PZ), $0.33(\mathrm{PF})$, and 0.27 (SF). Fig. 1b shows that W

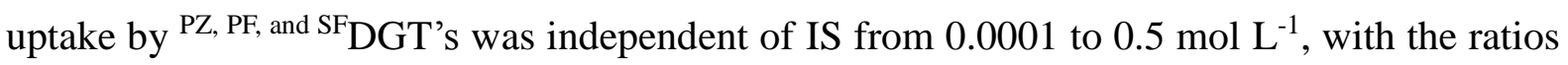


(0.87-0.90) for ferrihydrite DGT slightly lower than 0.9 at extreme IS conditions $\left(0.1 \mathrm{mmol} \mathrm{L}^{-1}\right.$ and $0.5 \mathrm{~mol} \mathrm{~L}^{-1}$ ). Considering the diffusive coefficient of $\mathrm{W}$ significantly increased at IS of 0.1 mmol L ${ }^{-1}$, DGT devices would not perform well under such low IS condition. Over all, ${ }^{\text {PZ, PF }}$ and SFDGT's are of good tolerance to variations of both $\mathrm{pH}(4.02-7.83)$ and IS (0.001-0.5 mol $\mathrm{L}^{-1}$ ), and ${ }^{\mathrm{PZ}} \mathrm{DGT}$ generally performed better than ${ }^{\text {ferrihydrite }}$ DGT, especially at higher $\mathrm{pH}$ (8.96). 3.4 Capacity of ${ }^{P Z, P F}$ and $S F D G T$ 'S

The masses of $\mathrm{W}$ accumulated by DGT onto the PZ, PF and SF gels initially increased linearly with solution concentration (Fig. 1c). The measured capacity of PZ, PF and SF gels $\geq 64 \mu \mathrm{g} \mathrm{W}$ per disc, equals to $\geq 25 \mu \mathrm{g} \mathrm{cm}^{-2}$ (divided by the exposure window area, here 2.51 $\mathrm{cm}^{2}$ ), which corresponds to a $\mathrm{W}$ concentration of $10 \mathrm{mg} \mathrm{L}^{-1}$ for at least $10 \mathrm{~h}$ deployment with a standard ${ }^{\mathrm{PZ}, \mathrm{PF} \text { or } \mathrm{SF}} \mathrm{DGT}$ device at $25^{\circ} \mathrm{C}$, respectively. If considering that $10 \%$ lower than the expected values are still acceptable [50], the capacity of the three samplers would be increased to $171(\mathrm{PZ}), 100(\mathrm{PF})$ and $80(\mathrm{SF}) \mu \mathrm{g} \mathrm{W}$ per disc. The relatively large $\mathrm{W}$ binding capacity of precipitated gels (PZ and PF) vs a slurry one (SF) is likely due to the greater exposed surface of the former ones, and, hence, a higher number of available adsorption sites [25, 33]. Overall, PZ or ferrihydriteDGT's are suitable for long-term or high-concentration deployment.

\subsection{Measurement of $W$ in soils using ${ }^{P Z, P F}$, and $S F D G T$ 's}

Soil property affects the bioavailability of metals in soils [51]. Soil SY was uncontaminated, whereas soils CZ and GZ were highly contaminated with W (82-196 mg kg${ }^{1}$ ) and other metals such as As (0.67-2.58 $\left.\mathrm{g} \mathrm{kg}^{-1}\right)$ (Tables 2 and S2). As for soil pH, soil SY was slightly acidic ( $\mathrm{pH}$ 6.5), whereas soils $\mathrm{CZ}$ and GZ were neutral ( $\mathrm{pH} 7.5$ and 7.4). Soils SY and GZ had relatively low concentrations of Fe (9.81 and $\left.11.8 \mathrm{~g} \mathrm{~kg}^{-1}\right), \mathrm{Mn}\left(0.51\right.$ and $\left.0.32 \mathrm{~g} \mathrm{~kg}^{-1}\right)$ and $\mathrm{Ca}\left(5.68\right.$ and $\left.3.15 \mathrm{~g} \mathrm{~kg}^{-1}\right)$. However, for soil $\mathrm{CZ}$, the contents were high (21.4 and $4.79 \mathrm{~g}$ $\mathrm{kg}^{-1}$ for Fe and Mn, respectively).

It is the first time that the DGT technique has been applied to study the bioavailability of $\mathrm{W}$ in soils. DGT-measured concentration, $C_{\mathrm{DGT}}$, incorporates the metal content in soil solution $\left(C_{\text {sol }}\right)$ and the supply flux from the labile pool of the solid phase $[52,53]$. As demonstrated in Table $2, C_{\text {DGT }}$ increased with soil and porewater $\mathrm{W}$ concentration. $R$ value (ratio of $C_{\text {DGT }}$ to $C_{\text {sol }}$ ) reflects the resupply potential of an element to the soil solution, providing an additional measure of the ability of a soil to maintain the $C_{\text {DGT }}$ flux [43]. Comparison of the soil $R$ values 
(0.06-0.09) from this study with those for other metals (Cd, $\mathrm{Zn}, \mathrm{Ni}$ and $\mathrm{As}$ ), encompassing a wide range of soil types [54-57], shows that typically $\mathrm{W}$ resupply is relatively poorly sustained. This is further supported by the high (>90\%) non-available residual fraction of $\mathrm{W}$ observed in acidic and neutral soils [10, 18, 58]. Johannesson et al., [59] concluded that W adsorption with mineral surface sites intensifies with increased $\mathrm{H}^{+}$and $\mathrm{Fe}$ concentrations in oxic, suboxic and anoxic groundwater systems. In this study, since the soil pH's are similar differing by less than $1 \mathrm{pH}$ unit (6.54 to 7.49), variation in $\mathrm{H}^{+}$concentration appears to be a less important factor affecting $\mathrm{W}$ bioavailability in soils than Fe concentration. This is demonstrated by the uncontaminated SY soil with the lowest Fe content, possessing higher average $R$ values $(0.09)$ than both the CZ and GZ W enriched soils (0.06). The $C_{\text {DGT }}$ ratios of the ferrihyrite (PF and SF)DGT's vs. the ${ }^{\mathrm{PZ}}$ DGT were within $17 \%$ of the value of unity, demonstrating a consistent measurement between the three sampler configurations.

\subsection{In situ high resolution profiling of $W$ in sediments}

The ability to determine whether sediment is a sink or source of W supply is fundamental to the utility of the high resolution DGT method. 1D vertical DGT profiles provide averaged lateral fluxes that can be used to parameterize numerical models for calculating sedimentoverlying water partitioning and $\mathrm{W}$ transfer. 1D profiling of $\mathrm{W}$ concentrations/fluxes across the SWI of sediments A and B from Lake Taihu is shown in Fig. 2 at two resolution: 5 mm and 0.1 $\mathrm{mm}$. Both methods reveal there to be little exchange between the two matrix compartments with the systems having approached a pseudo-equilibrium. Predicted apparent diffusion fluxes

for W (Sediment A, $-2.37 \times 10^{-2}$; Sediment B, $-8.63 \times 10^{-4} \mathrm{ng} \mathrm{cm}^{-2} \mathrm{~d}^{-1}$ ) were 2-3 orders of magnitude lower than reported values for P from Lake Taihu sediments [45], yet still indicated some marginal partitioning of $\mathrm{W}$ from the water column to the sediments. These observations fit the widely held hypothesis that $\mathrm{W}$ is a stable and inert metal compared with other trace elements. However, caution needs to be exercised when using this model to explain a sediment as a sink or source for a geochemically active element. If the element resupply, which is also captured by DGT, from the sediment solid phase is high, the obtained DGT concentrations below the SWI will be overestimated compared to those above the SWI. This will possibly induce an arbitrary/illusionary conclusion.

Toxicity risk assessment from $\mathrm{W}$ exposure may however be underestimated by $1 \mathrm{D}$ 
profiling, due to the heterogeneity of $\mathrm{W}$ and its associated minerals and the averaging/integration of microniches with bulk sediments within the measurement. For sediment dwelling organisms in contact with microniche zones $[31,35,60]$, exposures to $\mathrm{W}$ could be significantly higher than predicted by averaged 1D data. High resolution 2D DGT captures these chemical processes (Fig. 3), enabling a better understanding of both W geochemical cycling and exposure hazard. In the featured 2D sediment profile (Fig. 3), two hotspot zones were identified, one in the overlying water and the other at $8 \mathrm{~mm}$ below the SWI. The hotspot in water is possibly caused by sediment particle suspension along with the ebullition of piled gases from microbial respiration [61] or the swimming of benthic biota (such as Melita plumulosa) several millimeters above the SWI [62]. This phenomenon is also observed for other oxyanions, such as V, Mo and Sb, using high-resolution ${ }^{\mathrm{PF}} \mathrm{DGT}$ [23]. Average $\mathrm{W}$ fluxes $\left(\mathrm{n}=100\right.$, averaged measurements of each $1.5 \mathrm{~mm}^{2}$ ) from the hotspots expressed as a ratio of their bulk media equivalents, revealed W DGT fluxes in the overlying water were 1.5, whilst in the sediment this value was higher at 2 (Table S4). There inevitably existed lateral diffusion inside the DGT samplers, however, the resulting flux increase was determined to be $<9 \%$ [63]. Therefore, the above observed hotspots are generally the same size as in the media.

In addition to determining bioavailable solute fluxes, the $2 \mathrm{D}$ images can be used to measure the movement of the solute fronts of hotspots to bulk media, providing information on the zone's behavior, spatial distribution and fate. Using the same numerical modeling approaches as for interface diffusion, the apparent diffusion fluxes for the water $\left(2.07 \times 10^{-1} \mathrm{ng}\right.$ $\left.\mathrm{cm}^{-2} \mathrm{~d}^{-1}\right)$ and sediment $\left(2.28 \times 10^{-2} \mathrm{ng} \mathrm{cm}^{-2} \mathrm{~d}^{-1}\right)$ hotspots were calculated (Fig. 3, HS-B-I (1) and (2)). The intensity of the solute front flux in water was greater than the corresponding sediment interface, which results a greater element dispersion but the phenomena would be predicted to be less well sustained. The net flux of the apparent diffusion (Fig. 3) indicated that the two hotspots were still growing, i.e. element dispersion outwards. Since microbe could be a significant contributing factor of element desorption from (suspended) sediment particle [31, $64,65]$, it can be assumed that the microbial desorption rate of $\mathrm{W}$ from the particle is still higher than the diffusion rate, therefore, the hotspots can maintain their enlargement. It should be pointed out that the hotspots would turn from genesis to senescence eventually, and it will 
be interesting, though challenging, to capture the later process and depict the life cycle of the hotspots.

\section{Conclusions}

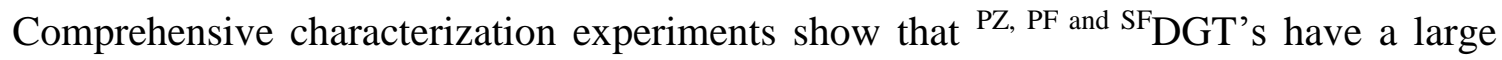
capacity for $\mathrm{W}$ measurement, and can be used in various environmental conditions with ionic strength of $0.001-0.5 \mathrm{~mol} \mathrm{~L}^{-1}$ and $\mathrm{pH}$ 's ranging between 4-8. Elution efficiencies of $100 \%$ and $90 \%$ were obtained for PZ and ferrihydrite (PF and SF) gels using $10 \mathrm{~mL}$ of $0.5 \mathrm{~mol} \mathrm{~L}^{-1} \mathrm{NaOH}$ and $1.4 \mathrm{~mol} \mathrm{~L}^{-1} \mathrm{HNO}_{3}+0.1 \mathrm{~mol} \mathrm{~L}^{-1} \mathrm{HF}$, respectively. The measured diffusion coefficient using an independent diffusion cell was $(6.63 \pm 0.13) \times 10^{-6} \mathrm{~cm}^{2} \mathrm{~s}^{-1}$ at $25^{\circ} \mathrm{C}$ with $\mathrm{NaNO}_{3}$ concentrations ranging from 0.001 to $0.5 \mathrm{~mol} \mathrm{~L}{ }^{-1}$. For the first time, $\mathrm{W}$ in soils was studied using the DGT technique, demonstrating the applicability of the tested DGT's. Nitric acid alone cannot effectively elute $\mathrm{W}$ from ferrihydrite gels, thus HF was added to get a stable high elution factor (0.9). HF is highly corrosive, and must be handled with extreme care. Because of this, and considering the long-time storage from production and higher binding capacity the PZ gels possess a number of practical advantages over its PF counterpart.

This work extended the application of PZ gel for measuring oxyanions to include W. In the future, ${ }^{\mathrm{PZ}} \mathrm{DGT}$ can be used to temporal monitoring of $\mathrm{W}$ in waters, adsorption/desorption kinetic study of W in soils with the aid of DIFS (DGT-induced fluxes in soils) modeling, highresolution mapping of $\mathrm{W}$ in contaminated sediments, and visual capturing of hotspots from genesis to senescence, providing new sights into micro-niche biogeochemistry in the earth's critical zone.

\section{Appendix A. Supplementary data}

Supplementary data associated with this article can be found in the online version, at http://dx.doi.org/......

\section{Acknowledgments}

This work was funded by the National Natural Science Foundation of China (NSFC) (No. 21477053), the NSFC and Newton Fund/Royal Society (No. 21511130063 and R1504GFS) and the program B for Outstanding PhD candidate of Nanjing University (201501B020). 


\section{References}

[1] J.F. Kalinich, C.A. Emond, T.K. Dalton, S.R. Mog, G.D. Coleman, J.E. Kordell, A.C. Miller, D.E. McClain, Embedded weapons-grade tungsten alloy shrapnel rapidly induces metastatic high-grade rhabdomyosarcomas in F344 rats, Environ. Health Perspect. 113 (2005) 729-734.

[2] A.D. Kelly, M. Lemaire, Y.K. Young, J.H. Eustache, C. Guilbert, M.F. Molina, K.K. Mann, In vivo tungsten exposure alters B-cell development and increases DNA damage in murine bone marrow, Toxicol. Sci. 131 (2013) 434-446. [3] F. Laulicht, J. Brocato, L. Cartularo, J. Vaughan, F. Wu, T. Kluz, H. Sun, B.A. Oksuz, S. Shen, M. Peana, S. Medici, M.A. Zoroddu, M. Costa, Tungsten-induced carcinogenesis in human bronchial epithelial cells, Toxicol. Appl. Pharmacol. 288 (2015) 33-39.

[4] V.G. Thomas, M.J. Roberts, P.T. Harrison, Assessment of the environmental toxicity and carcinogenicity of tungsten-based shot, Ecotoxicol. Environ. Saf. 72 (2009) 1031-1037.

[5] A. Koutsospyros, W. Braida, C. Christodoulatos, D. Dermatas, N. Strigul, A review of tungsten: from environmental obscurity to scrutiny, J. Hazard. Mater. 136 (2006) 1-19.

[6] S.C. Hsu, H.L. Hsieh, C.P. Chen, C.M. Tseng, S.C. Huang, C.H. Huang, Y.T. Huang, V. Radashevsky, S.H. Lin, Tungsten and other heavy metal contamination in aquatic environments receiving wastewater from semiconductor manufacturing, J. Hazard. Mater. 189 (2011) 193-202.

[7] P. Schade, 100 years of doped tungsten wire, Int. J. Refract. Met. Hard Mat. 28 (2010) 648-660.

[8] N. Ji, T. Zhang, M.Y. Zheng, A.Q. Wang, H. Wang, X.D. Wang, J.G.G. Chen, Direct catalytic conversion of cellulose into ethylene glycol using nickel-promoted tungsten carbide catalysts, Angew. Chem.-Int. Edit. 47 (2008) 85108513.

[9] J.L. Clausen, N. Korte, Environmental fate of tungsten from military use, Sci. Total Environ. 407 (2009) 28872893.

[10] C. Lin, R. Li, H. Cheng, J. Wang, X. Shao, Tungsten distribution in soil and rice in the vicinity of the world's largest and longest-operating tungsten mine in China, PLoS One 9 (2014) e91981.

[11] S. Xu, C. Lin, P. Qiu, Y. Song, W. Yang, G. Xu, X. Feng, Q. Yang, X. Yang, A. Niu, Tungsten- and cobalt-dominated heavy metal contamination of mangrove sediments in Shenzhen, China, Mar. Pollut. Bull. 100 (2015) 562-566.

[12] L. Luo, K.J. Liu, A. Shibayama, W.T. Yen, T. Fujita, O. Shindo, A. Katai, Recovery of tungsten and vanadium from tungsten alloy scrap, Hydrometallurgy 72 (2004) 1-8.

[13] C. Steinmaus, M. Lu, R.L. Todd, A.H. Smith, Probability estimates for the unique childhood leukemia cluster in Fallon, Nevada, and risks near other US Military aviation facilities, Environ. Health Perspect. 112 (2004) 766 771.

[14] R. Clemente, N.W. Lepp, Tungsten, in: B.J. Alloway (Ed.) Heavy Metals in Soils, Springer Netherlands, 2013, pp. 559-564.

[15] C. Hobson, Exploring tungsten in the enironment: geochemical study of an emerging contaminant, in, Kansas State University, 2014.

[16] A.J. Kennedy, D.R. Johnson, J.M. Seiter, J.H. Lindsay, R.E. Boyd, A.J. Bednar, P.G. Allison, Tungsten toxicity, bioaccumulation, and compartmentalization into organisms representing two trophic levels, Environ. Sci. Technol. 46 (2012) 9646-9652.

[17] N. Strigul, A. Koutsospyros, P. Arienti, C. Christodoulatos, D. Dermatas, W. Braida, Effects of tungsten on environmental systems, Chemosphere 61 (2005) 248-258.

[18] U.S.EPA, Emerging contaminant - tungsten, 2008 EPA 505-F-07-005. , in.

[19] N.K. Cutler, The geochemistry of groundwater and sediments governing tungsten concentration in the basinfill aquifers Fallon, Nevada, in, University of Nevada, Reno, 2011. 
[20] R.L. Seiler, K.G. Stollenwerk, J.R. Garbarino, Factors controlling tungsten concentrations in ground water, Carson Desert, Nevada, Appl. Geochem. 20 (2005) 423-441.

[21] A.J. Bednar, W.T. Jones, R.E. Boyd, D.B. Ringelberg, S.L. Larson, Geochemical parameters influencing tungsten mobility in soils, J. Environ. Qual. 37 (2008) 229-233.

[22] B. Vrana, G.A. Mills, I.J. Allan, E. Dominiak, K. Svensson, J. Knutsson, G. Morrison, R. Greenwood, Passive sampling techniques for monitoring pollutants in water, TrAC, Trends Anal. Chem. 24 (2005) 845-868.

[23] A. Stockdale, W. Davison, H. Zhang, 2D simultaneous measurement of the oxyanions of P, V, As, Mo, Sb, W and U, J. Environ. Monit. 12 (2010) 981-984.

[24] J.G. Panther, R.R. Stewart, P.R. Teasdale, W.W. Bennett, D.T. Welsh, H. Zhao, Titanium dioxide-based DGT for measuring dissolved $\mathrm{As}(\mathrm{V}), \mathrm{V}(\mathrm{V}), \mathrm{Sb}(\mathrm{V}), \mathrm{Mo}(\mathrm{VI})$ and $\mathrm{W}(\mathrm{VI})$ in water, Talanta 105 (2013) 80-86.

[25] D.X. Guan, P.N. Williams, J. Luo, J.L. Zheng, H.C. Xu, C. Cai, L.Q. Ma, Novel precipitated zirconia-based DGT technique for high-resolution imaging of oxyanions in waters and sediments, Environ. Sci. Technol. 49 (2015) 3653-3661.

[26] Y. Pan, D.X. Guan, D. Zhao, J. Luo, H. Zhang, W. Davison, L.Q. Ma, Novel speciation method based on diffusive gradients in thin-films for in situ measurement of $\mathrm{Cr}^{\mathrm{Vl}}$ in aquatic systems, Environ. Sci. Technol. 49 (2015) 1426714273.

[27] H. Zhang, W. Davison, Performance characteristics of diffusion gradients in thin films for the in situ measurement of trace metals in aqueous solution, Anal. Chem. 67 (1995) 3391-3400.

[28] J.G. Panther, W.W. Bennett, D.T. Welsh, P.R. Teasdale, Simultaneous measurement of trace metal and oxyanion concentrations in water using diffusive gradients in thin films with a Chelex-Metsorb mixed binding layer, Anal. Chem. 86 (2014) 427-434.

[29] H. Österlund, S. Chlot, M. Faarinen, A. Widerlund, I. Rodushkin, J. Ingri, D.C. Baxter, Simultaneous measurements of As, Mo, Sb, V and $\mathrm{W}$ using a ferrihydrite diffusive gradients in thin films (DGT) device, Anal. Chim. Acta 682 (2010) 59-65.

[30] K.W. Warnken, H. Zhang, W. Davison, Performance characteristics of suspended particulate reagent-iminodiacetate as a binding agent for diffusive gradients in thin films, Anal. Chim. Acta 508 (2004) 4151.

[31] A. Stockdale, W. Davison, H. Zhang, Micro-scale biogeochemical heterogeneity in sediments: A review of available technology and observed evidence, Earth Sci. Rev. 92 (2009) 81-97.

[32] Ł. Sochaczewski, W. Davison, H. Zhang, W. Tych, Understanding small-scale features in DGT measurements in sediments, Environ. Chem. 6 (2009) 477-485.

[33] J. Luo, H. Zhang, J. Santner, W. Davison, Performance characteristics of diffusive gradients in thin films equipped with a binding gel layer containing precipitated ferrihydrite for measuring arsenic(V), selenium(VI), vanadium(V), and antimony(V), Anal. Chem. 82 (2010) 8903-8909.

[34] A. Kreuzeder, J. Santner, T. Prohaska, W.W. Wenzel, Gel for simultaneous chemical imaging of anionic and cationic solutes using diffusive gradients in thin films, Anal. Chem. 85 (2013) 12028-12036.

[35] P.N. Williams, J. Santner, M. Larsen, N.J. Lehto, E. Oburger, W. Wenzel, R.N. Glud, W. Davison, H. Zhang, Localized flux maxima of arsenic, lead, and iron around root apices in flooded lowland rice, Environ. Sci. Technol. 48 (2014) 8498-8506.

[36] J. Santner, T. Prohaska, J. Luo, H. Zhang, Ferrihydrite containing gel for chemical imaging of labile phosphate species in sediments and soils using diffusive gradients in thin films, Anal. Chem. 82 (2010) 7668-7674.

[37] H. Zhang, W. Davison, R. Gadi, T. Kobayashi, In situ measurement of dissolved phosphorus in natural waters using DGT, Anal. Chim. Acta 370 (1998) 29-38.

[38] M.P. Harper, W. Davison, H. Zhang, W. Tych, Kinetics of metal exchange between solids and solutions in 
sediments and soils interpreted from DGT measured fluxes, Geochim. Cosmochim. Acta 62 (1998) 2757-2770. [39] J.L. Zheng, D.X. Guan, J. Luo, H. Zhang, W. Davison, X.Y. Cui, L.H. Wang, L.Q. Ma, Activated charcoal based diffusive gradients in thin films for in situ monitoring of bisphenols in waters, Anal. Chem. 87 (2015) 801-807.

[40] J.M. Garnier, J. Garnier, D. Jézéquel, B. Angeletti, Using DET and DGT probes (ferrihydrite and titanium dioxide) to investigate arsenic concentrations in soil porewater of an arsenic-contaminated paddy field in Bangladesh, Sci. Total Environ. 536 (2015) 306-315.

[41] ISO, 10390: 2005 Soil quality - Determination of $\mathrm{pH}$, in.

[42] O. Priha, A. Smolander, Nitrogen transformations in soil under Pinus sylvestris, Picea abies and Betula pendula at two forest sites, Soil Biol. Biochem. 31 (1999) 965-977.

[43] J. Luo, H. Cheng, J. Ren, W. Davison, H. Zhang, Mechanistic insights from DGT and soil solution measurements on the uptake of $\mathrm{Ni}$ and $\mathrm{Cd}$ by radish, Environ. Sci. Technol. 48 (2014) 7305-7313.

[44] A. Stockdale, W. Davison, H. Zhang, High-resolution two-dimensional quantitative analysis of phosphorus, vanadium and arsenic, and qualitative analysis of sulfide, in a freshwater sediment, Environ. Chem. 5 (2008) 143149.

[45] S. Ding, C. Han, Y. Wang, L. Yao, Y. Wang, D. Xu, Q. Sun, P.N. Williams, C. Zhang, In situ, high-resolution imaging of labile phosphorus in sediments of a large eutrophic lake, Water Res. 74 (2015) 100-109.

[46] Y.H. Li, S. Gregory, Diffusion of ions in sea water and in deep-sea sediments, Geochim. Cosmochim. Acta 38 (1974) 703-714.

[47] Y. Gao, L. Lesven, D. Gillan, K. Sabbe, G. Billon, S. De Galan, M. Elskens, W. Baeyens, M. Leermakers, Geochemical behavior of trace elements in sub-tidal marine sediments of the Belgian coast, Mar. Chem. 117 (2009) 88-96.

[48] K.W. Warnken, H. Zhang, W. Davison, Trace metal measurements in low ionic strength synthetic solutions by diffusive gradients in thin films, Anal. Chem. 77 (2005) 5440-5446.

[49] A.H. Shiva, P.R. Teasdale, W.W. Bennett, D.T. Welsh, A systematic determination of diffusion coefficients of trace elements in open and restricted diffusive layers used by the diffusive gradients in a thin film technique, Anal. Chim. Acta 888 (2015) 146-154.

[50] H.L. Price, P.R. Teasdale, D.F. Jolley, An evaluation of ferrihydrite- and Metsorb-DGT techniques for measuring oxyanion species (As, Se, V, P): effective capacity, competition and diffusion coefficients, Anal. Chim. Acta 803 (2013) 56-65.

[51] S. Liang, D.X. Guan, J.H. Ren, M. Zhang, J. Luo, L.Q. Ma, Effect of aging on arsenic and lead fractionation and availability in soils: coupling sequential extractions with diffusive gradients in thin-films technique, J. Hazard. Mater. 273 (2014) 272-279.

[52] J. Luo, H. Zhang, W. Davison, R.G. McLaren, L.M. Clucas, L.Q. Ma, X.R. Wang, Localised mobilisation of metals, as measured by diffusive gradients in thin-films, in soil historically treated with sewage sludge, Chemosphere 90 (2013) 464-470.

[53] Y. Tian, X. Wang, J. Luo, H. Yu, H. Zhang, Evaluation of holistic approaches to predicting the concentrations of metals in field-cultivated rice, Environ. Sci. Technol. 42 (2008) 7649-7654.

[54] H. Zhang, W. Davison, A.M. Tye, N.M.J. Crout, S.D. Young, Kinetics of zinc and cadmium release in freshly contaminated soils, Environ. Toxicol. Chem. 25 (2006) 664-670.

[55] H. Ernstberger, H. Zhang, A. Tye, S. Young, W. Davison, Desorption kinetics of Cd, Zn, and Ni measured in soils by DGT, Environ. Sci. Technol. 39 (2005) 1591-1597.

[56] J.Y. Xu, H.B. Li, S. Liang, J. Luo, L.Q. Ma, Arsenic enhanced plant growth and altered rhizosphere characteristics of hyperaccumulator Pteris vittata, Environ. Pollut. 194 (2014) 105-111.

[57] P.N. Williams, H. Zhang, W. Davison, A.A. Meharg, M. Hossain, G.J. Norton, H. Brammer, M.R. Islam, Organic 
matter-solid phase interactions are critical for predicting arsenic release and plant uptake in Bangladesh paddy soils, Environ. Sci. Technol. 45 (2011) 6080-6087.

[58] B. Wilson, F.B. Pyatt, Bio-availability of tungsten in the vicinity of an abandoned mine in the English Lake District and some potential health implications, Sci. Total Environ. 370 (2006) 401-408.

[59] K.H. Johannesson, H.B. Dave, T.J. Mohajerin, S. Datta, Controls on tungsten concentrations in groundwater flow systems: The role of adsorption, aquifer sediment Fe(III) oxide/oxyhydroxide content, and thiotungstate formation, Chem. Geol. 351 (2013) 76-94.

[60] Y. Gao, S. van de Velde, P.N. Williams, W. Baeyens, H. Zhang, Two-dimensional images of dissolved sulfide and metals in anoxic sediments by a novel diffusive gradients in thin film probe and optical scanning techniques, TrAC, Trends Anal. Chem. 66 (2015) 63-71.

[61] C.H. Cheng, M. Huettel, R.A. Wildman, Ebullition-enhanced solute transport in coarse-grained sediments, Limnology and Oceanography 59 (2014) 1733-1748.

[62] O. Campana, S.L. Simpson, D.A. Spadaro, J. Blasco, Sub-lethal effects of copper to benthic invertebrates explained by sediment properties and dietary exposure, Environ. Sci. Technol. 46 (2012) 6835-6842.

[63] J. Santner, A. Kreuzeder, A. Schnepf, W.W. Wenzel, Numerical evaluation of lateral diffusion inside diffusive gradients in thin films samplers, Environ. Sci. Technol. 49 (2015) 6109-6116.

[64] T.Y. Lin, C.C. Wei, C.W. Huang, C.H. Chang, F.L. Hsu, V.H. Liao, Both Phosphorus Fertilizers and Indigenous Bacteria Enhance Arsenic Release into Groundwater in Arsenic-Contaminated Aquifers, J. Agric. Food. Chem. 64 (2016) 2214-2222.

[65] N. Yang, Z. Shen, S. Datta, K.H. Johannesson, High arsenic (As) concentrations in the shallow groundwaters of southern Louisiana: Evidence of microbial controls on As mobilization from sediments, Journal of Hydrology: Regional Studies 5 (2016) 100-113. 
Figure captions:

Fig. 1. Effects of $\mathrm{pH}$ (a) and ionic strength (IS) (b) on the ratio of DGT-measured concentrations of $\mathrm{W}, C_{\mathrm{DGT}}$, to deployment solution concentrations, $C_{\mathrm{sol}}$, and dependence of mass of W accumulated by DGT on solution concentration (c). PZ, PF and SF represent DGT devices containing precipitated zirconia, precipitated ferrihydrite and slurry ferrihydrite gels, respectively. The solid horizontal line and dotted horizontal lines in (a) and (b) represent target values of $1.0 \pm 0.1$. The solid and dotted inclined lines in (c) were the $100 \%$ and $90 \%$ theoretical slopes calculated from known concentrations in solution, respectively. Error bars represent the standard deviation $(\mathrm{n}=3)$.

Fig. 2. Distribution of $\mathrm{W}$ across the sediment-water interface (SWI) of two freshwater sediments (A and B): (a) 1D sub-cm profile in sediment A obtained by gel slicing at an interval of $5 \mathrm{~mm}$; (b) 1D sub-mm high resolution (100 $\mu \mathrm{m}$ vertically) in sediment B obtained by averaging the data from Figure 3 across the SWI $(+/-4.5 \mathrm{~mm})$. The light blue and dark brown in (a) and (b) indicate overlying water and sediment, respectively. The arrow direction denotes the net flux (NF) of the apparent diffusion.

Fig. 3. 3D plotting of $\mathrm{W}$ fluxes $\left(\mathrm{pg} \mathrm{cm}^{-2} \mathrm{~s}^{-1}\right)$ in a sediment (B) from Lake Taihu. SWI and HSB-I denote the sediment-water interface and the hotspot-bulk media interface, respectively. The white solid lines indicate the measurement regions (+/- $2 \mathrm{~mm})$ used to calculate the apparent diffusion flux across the interface zones, HS-B-I (1) and (2). The arrow direction denotes the net flux (NF) of the apparent diffusion. 

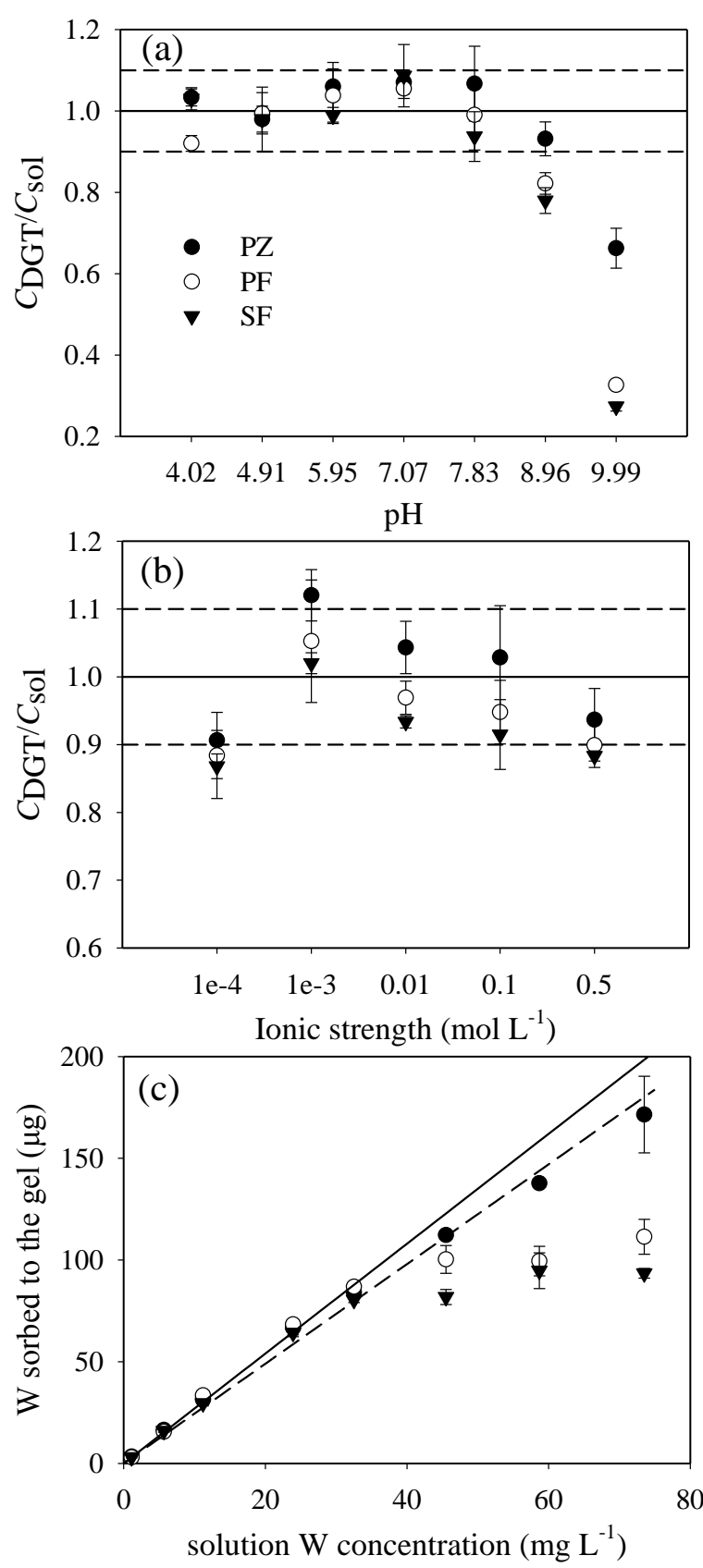

Fig. 1. 


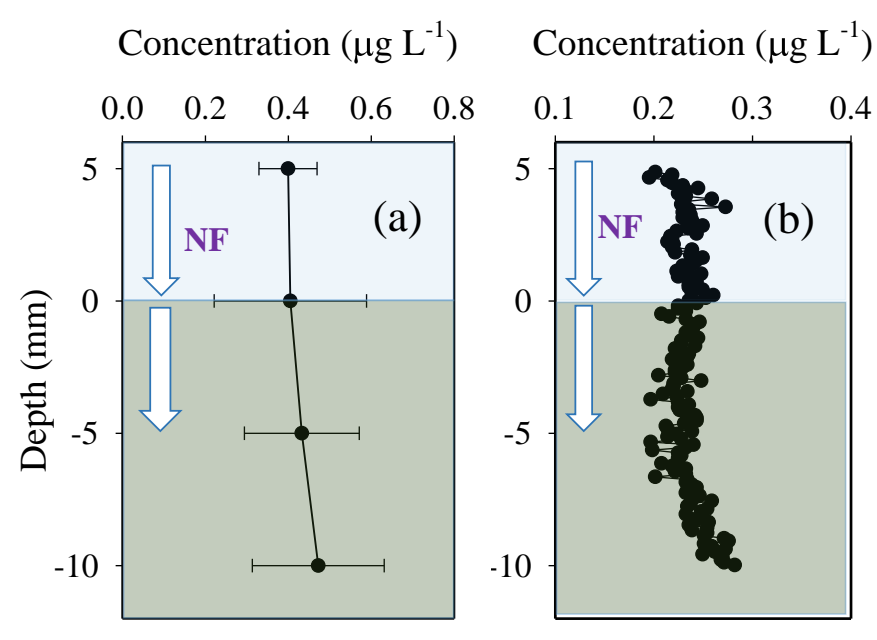

Fig. 2. 


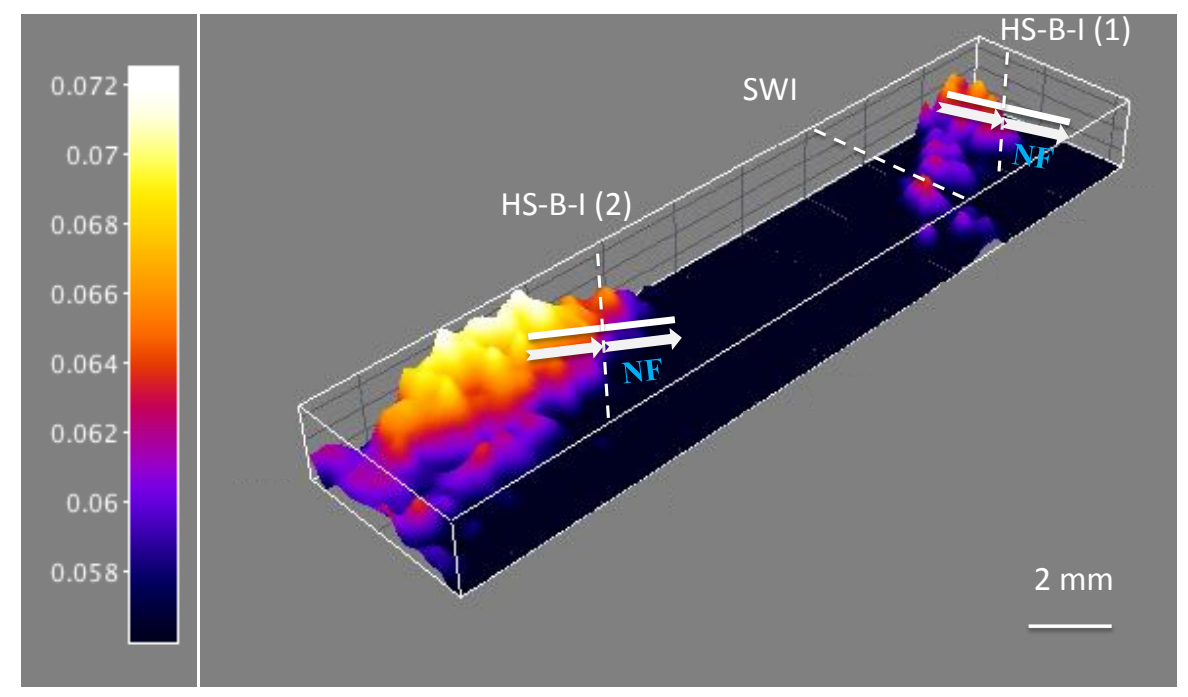

Fig. 3. 
Table 1. Measured and reported diffusion coefficient using a diffusion cell ( $\left.D_{\text {cell }}\right)$ and DGT devices $\left(D_{\text {DGT }}\right)$ at $25^{\circ} \mathrm{C}$

\begin{tabular}{lll}
\hline$D_{\text {cell }}$ & $D_{\text {DGT }}$ & Reference \\
\hline $6.63 \pm 0.13^{\mathrm{a}}$ & $6.31^{\mathrm{d}}$ & In this study \\
$9.26^{\mathrm{b}}$ & & \\
$6.60^{\mathrm{c}}$ & & \\
$6.89 \pm 0.08$ & $6.26 \pm 0.37$ & {$[24]$} \\
$5.45 \pm 0.20$ & $5.56 \pm 0.56$ & {$[29]$} \\
$6.22 \pm 0.11$ & $6.88 \pm 0.47$ & {$[28]$} \\
$4.28 \pm 0.22$ & $6.50 \pm 0.34$ & {$[48]$} \\
\hline
\end{tabular}

${ }^{a}$ measured in solutions with the concentrations of matrix $\mathrm{NaNO}_{3}$ at $0.001,0.01$ and $0.5 \mathrm{~mol}$ $\mathrm{L}^{-1}$ and calculated from Fig. S2(a-c), the standard deviation is from the three measurement; ${ }^{b}$ measured in solutions with the ultralow concentration of matrix $\mathrm{NaNO}_{3}$ at $0.1 \mathrm{mmol} \mathrm{L}^{-1}$ and calculated from Fig. S2(d); ${ }^{c}$ measured with freshwater as the matrix and calculated from Fig. S2(e); ${ }^{\text {d }}$ calculated from the fitted linear equation from Fig. S1(c). 
Table 2. Soil properties, soil solution $\left(C_{\text {sol }}\right)$ and DGT-measured $\left(C_{\text {PZ/PF/SF-DGT }}\right)$ concentrations of W

\begin{tabular}{|c|c|c|c|}
\hline Soils & SY & $\mathrm{CZ}$ & GZ \\
\hline Soil type & luvisol & ferrisol & ferrisol \\
\hline $\mathrm{pH}^{\mathrm{a}}$ & 6.54 & 7.49 & 7.37 \\
\hline WHC & 42.1 & 49.7 & 41.0 \\
\hline Total Fe $\left(\mathrm{g} \mathrm{kg}^{-1}\right)^{\mathrm{b}}$ & $9.81 \pm 0.66$ & $21.4 \pm 0.60$ & $11.8 \pm 0.41$ \\
\hline Total Mn $\left(\mathrm{g} \mathrm{kg}^{-1}\right)^{\mathrm{b}}$ & $0.51 \pm 0.01$ & $4.79 \pm 0.02$ & $0.32 \pm 0.04$ \\
\hline Total Ca $\left(\mathrm{g} \mathrm{kg}^{-1}\right)^{\mathrm{b}}$ & $5.68 \pm 0.34$ & $19.1 \pm 0.75$ & $3.15 \pm 0.28$ \\
\hline As $\left(\mathrm{mg} \mathrm{kg}^{-1}\right)^{\mathrm{b}}$ & $4.92 \pm 0.61$ & $667 \pm 0.36$ & $2,578 \pm 132$ \\
\hline $\mathrm{W}\left(\mathrm{mg} \mathrm{kg}^{-1}\right)^{\mathrm{c}}$ & $-{ }^{d}$ & $82 \pm 53$ & $196 \pm 50$ \\
\hline$C_{\text {sol }}\left(\mu \mathrm{g} \mathrm{L}^{-1}\right)$ & $1.71 \pm 0.13$ & $10.0 \pm 0.20$ & $192 \pm 6.02$ \\
\hline$C_{\text {PZ-DGT }}\left(\mu \mathrm{g} \mathrm{L}^{-1}\right)$ & $0.21 \pm 0.03$ & $0.60 \pm 0.02$ & $13.9 \pm 0.38$ \\
\hline$C_{\text {PF-DGT }}\left(\mu \mathrm{g} \mathrm{L}^{-1}\right)$ & $0.13 \pm 0.01$ & $0.67 \pm 0.04$ & $10.8 \pm 0.54$ \\
\hline$C_{\text {SF-DGT }}\left(\mu \mathrm{g} \mathrm{L}^{-1}\right)$ & $0.14 \pm 0.02$ & $0.63 \pm 0.03$ & $10.9 \pm 0.50$ \\
\hline$R$ value $^{\mathrm{e}}$ & $0.08-0.12$ & $0.06-0.07$ & $0.06-0.07$ \\
\hline
\end{tabular}




\section{Highlights}

- Two high-resolution diffusive gradients in thin-films samplers were characterized.

- For the first time DGT was applied to study the bioavailability of W in soils.

- $1 \mathrm{D}$ and 2D high resolution profiling of W fluxes across the SWI were obtained.

- The apparent diffusion W fluxes across two micro-interfaces were calculated. 